\title{
Reusability of Al-F Hydroxide Precipitates Generated in Adsorption and Coagulation Treatment of Fluoride for Adsorptive Removal of Arsenic
}

\author{
Jiawei Ju,,2 Zan He, ${ }^{1,2}$ Ruiping Liu,, ${ }^{1, *}$ Huijuan Liu, Xiwang Zhang, ${ }^{3}$ and Jiuhui Qu ${ }^{1}$ \\ ${ }^{1}$ Key Laboratory of Aquatic Science and Technology, Research Center for Eco-Environmental Sciences, \\ Chinese Academy of Sciences, Beijing, China. \\ ${ }^{2}$ College of Resources and Environment, University of Chinese Academy of Sciences, Beijing, China. \\ ${ }^{3}$ Department of Chemical Engineering, Monash University, Clayton, Australia.
}

Received: June 10, $2014 \quad$ Accepted in revised form: April 14, 2015

\begin{abstract}
This study aims to investigate the feasibility of utilizing Al-F hydroxide precipitates generated in $\mathrm{Al}$ hydroxide $\left[\mathrm{Al}(\mathrm{OH})_{3}\right]$ adsorption $\left[\mathrm{Al}(\mathrm{OH})_{3}-\mathrm{F}_{\text {ads }}\right]$ and aluminum $(\mathrm{Al})$ coagulation $\left[\mathrm{Al}(\mathrm{OH})_{3}-\mathrm{F}_{\text {coag }}\right]$ for adsorptive removal of $\mathrm{As}(\mathrm{III})$ and $\mathrm{As}(\mathrm{V}) . \mathrm{Al}(\mathrm{OH})_{3}-\mathrm{F}_{\text {ads }}, \mathrm{Al}(\mathrm{OH})_{3}-\mathrm{F}_{\text {coag }}$, and pristine $\mathrm{Al}(\mathrm{OH})_{3}$ were characterized by nitrogen sorption, $\mathrm{X}$-ray photoelectron spectroscopy, and fourier transform infrared spectroscopy (FTIR) before and after arsenic adsorption. The kinetic study indicated that $\mathrm{As}(\mathrm{III})$ and $\mathrm{As}(\mathrm{V})$ adsorption on these Al-based solid wastes followed the pseudo-second-order model. The calculated adsorption capacity of $\mathrm{Al}(\mathrm{OH})_{3}-\mathrm{F}_{\text {ads }}$ and $\mathrm{Al}(\mathrm{OH})_{3}-\mathrm{F}_{\text {coag }}$ for $\mathrm{As}(\mathrm{III})$ was 48.0 and $31.0 \mathrm{mg} / \mathrm{g}$, while it was 84.0 and $56.3 \mathrm{mg} / \mathrm{g}$ for As(V), respectively. These adsorption capacities were 25-50\% lower compared with pristine $\mathrm{Al}(\mathrm{OH})_{3}$. Anion exchange of fluoride by $\mathrm{H}_{2} \mathrm{AsO}_{4}{ }^{-}$and $\mathrm{HAsO}_{4}{ }^{2-}$ dominated in $\mathrm{As}(\mathrm{V})$ removal by $\mathrm{Al}(\mathrm{OH})_{3}-\mathrm{F}_{\text {ads }}$, while formation of an As-O complex played a more important role in $\mathrm{As}(\mathrm{V})$ removal by $\mathrm{Al}(\mathrm{OH})_{3}-\mathrm{F}_{\text {coag. The maximum concentration of released fluoride after the adsorption of } \mathrm{As}(\mathrm{III}) \text { and }}$ $\mathrm{As}(\mathrm{V})$ by $\mathrm{Al}(\mathrm{OH})_{3}-\mathrm{F}_{\text {ads }}$ and $\mathrm{Al}(\mathrm{OH})_{3}-\mathrm{F}_{\text {coag }}$ was below the Chinese Class-II industrial discharge standard for fluoride $(<20 \mathrm{mg} / \mathrm{L})$. Results from this study indicated that the aluminum hydroxides generated in the fluoride removal process could be reclaimed as an adsorbent for $\mathrm{As}(\mathrm{III}) / \mathrm{As}(\mathrm{V})$ removal from industrial wastewater.
\end{abstract}

Key words: adsorption; $\mathrm{Al}(\mathrm{OH})_{3}$; arsenic; fluoride; reclamation

\section{Introduction}

T HE CONTAMINATION OF toxic arsenic (As) due to geochemical reactions and anthropic activities is a worldwide challenge to ecological safety and human health. Inorganic arsenic in water primarily exists in two oxidation states, neutral arsenite [As(III)] and negatively charged arsenate $[\mathrm{As}(\mathrm{V})]$. Many technologies have been tested and applied for arsenic removal, including oxidation/precipitation (Borho and Wilderer, 1996; Leupin and Hug, 2005), coagulation/coprecipitation (Cheng et al., 1994; Hering et al., 1997; Wickramasinghe et al., 2004), adsorption (Guo et al., 2007; Maiti et al., 2012), ion exchange (Kim and Benjamin, 2004; Baciocchi et al., 2005), reverse osmosis (Kang et al., 2000; Ning, 2002), electrodialysis (Weng et al., 2005), and bioremediation (Katsoyiannis et al., 2002). Among them, adsorption is one of the most widely used technologies due to its easy operation and maintenance, high efficiency, and low cost.

*Corresponding author: Key Laboratory of Aquatic Science and Technology, Research Center for Eco-Environmental Sciences, Chinese Academy of Sciences, Beijing 100085, China. Phone: +86 10 62849128; Fax: +86 10 62849160; E-mail: liuruiping@ rcees.ac.cn
In the past decade, much effort has been focused on the development of novel adsorbents with high removal capacity, such as nanocrystalline $\mathrm{TiO}_{2}$ (Xu and Meng, 2009), treated laterite (Guo et al., 2007; Maiti et al., 2012), iron and manganese binary oxide (Wu et al., 2011), and magnetite $\mathrm{Fe}_{3} \mathrm{O}_{4^{-}}$ reduced graphite oxide (Luo et al., 2012). However, their high fabrication cost limits their wide application in practice. Most recently, some low-cost adsorbents such as agricultural and industrial by-products have been investigated for arsenic removal (Soner Altundoğan et al., 2000; Mandal et al., 2012). For instance, Mandal et al. (2012) studied the adsorption of $\mathrm{As}(\mathrm{III})$ and $\mathrm{As}(\mathrm{V})$ by the mangrove sediment, and results showed that ligand exchange and adsorption reactions occurred in both organic matter and the hydroxide phase (Mandal et al., 2012). Industrial waste such as red mud and iron oxide-loaded melted municipal solid waste incinerator slag was also tested, and the calculated maximum adsorption capacity for As(III) and As(V) was 8.86 and $10.80 \mu \mathrm{mol} / \mathrm{g}$, respectively. Besides, the adsorption of As(III) onto red mud was exothermic, whereas that of $\mathrm{As}(\mathrm{V})$ was endothermic (Soner Altundoğan et al., 2000).

Fluorosis due to the long-term exposure to fluoride through drinking water is another global health concern. Aluminum (Al) coagulation and $\mathrm{Al}$ (hydro) oxide adsorption have been 
well studied and widely used for fluoride removal. However, the large amounts of aluminum hydroxide solid wastes generated in both processes have created a high demand for more environmentally benign and cost-effective alternatives. One option that exhibits a promising future is the conversion of the solid wastes into adsorbents. With our knowledge of the solid wastes having a high porosity and an affinity for arsenic, we aim to investigate the feasibility of using the solid wastes as sorbents for arsenic removal in this study. Furthermore, the fluoride removal mechanisms and the speciation of fluoride involved in these two systems are different. In $\mathrm{Al}$ (hydro) oxide adsorption, fluoride is mostly adsorbed on the surface of adsorbents. By contrast, in coagulation, fluoride participates in the formation of aluminum hydroxide $\left[\mathrm{Al}(\mathrm{OH})_{3}\right]$ precipitates, and hence, it is captured inside the particles besides attaching to the surfaces. In addition, the different states of fluoride may affect the interfacial characteristics of these two wastes which, in turn, affect their performance in arsenic removal.

In this study, we aim to investigate the feasibility of reusing two kinds of solid wastes generated in the adsorption and coagulation treatment of fluoride as adsorbents for arsenic removal. The solid wastes obtained from the adsorption process were mainly $\mathrm{Al}(\mathrm{OH})_{3}$ flocs with adsorbed fluoride, which were named as $\mathrm{Al}(\mathrm{OH})_{3}-\mathrm{F}_{\text {ads }}$. However, the solid wastes obtained from the coagulation process were mainly $\mathrm{Al}-\mathrm{F}-\mathrm{OH}$ precipitates, which were named as $\mathrm{Al}(\mathrm{OH})_{3}-\mathrm{F}_{\text {coag. }}$. The adsorption performance of $\mathrm{Al}(\mathrm{OH})_{3}-\mathrm{F}_{\text {ads }}, \mathrm{Al}(\mathrm{OH})_{3}-\mathrm{F}_{\text {coag }}$, and pristine $\mathrm{Al}(\mathrm{OH})_{3}$ for $\mathrm{As}(\mathrm{III})$ and $\mathrm{As}(\mathrm{V})$ removal was evaluated in terms of adsorption isotherms and adsorption kinetics. These adsorbents before and after arsenic adsorption were characterized by X-ray photoelectron spectroscopy (XPS), fourier transform infrared spectroscopy (FTIR), BrunauerEmmett-Teller (BET) surface area analyzer, and sequential extraction procedures to illustrate the adsorption mechanism.

\section{Chemicals and Methods}

\section{Chemicals}

All chemicals used in this study were of analytical grade. The stock solutions of $\mathrm{As}(\mathrm{III}), \mathrm{As}(\mathrm{V})$, fluoride, and $\mathrm{Al}$ salt were prepared by dissolving $\mathrm{NaAsO}_{2}, \mathrm{Na}_{3} \mathrm{AsO}_{4}, \mathrm{NaF}$, and $\mathrm{AlCl}_{3} \cdot 6 \mathrm{H}_{2} \mathrm{O}$ in deionized water, respectively.

\section{Preparation of $\mathrm{Al}(\mathrm{OH})_{3}-\mathrm{F}$ solid wastes}

A plexiglass beaker on a conventional Jar test apparatus was used to fabricate the three adsorbents, $\mathrm{Al}(\mathrm{OH})_{3}-\mathrm{F}_{\text {ads }}$, $\mathrm{Al}(\mathrm{OH})_{3}-\mathrm{F}_{\text {coag }}$, and pristine $\mathrm{Al}(\mathrm{OH})_{3}$. First, $\mathrm{NaOH}$ solution $(1.25 \mathrm{M})$ was slowly added into $500 \mathrm{~mL} \mathrm{AlCl}{ }_{3} \cdot 6 \mathrm{H}_{2} \mathrm{O}$ solution $(20 \mathrm{mmo} / \mathrm{L})$ under stirring at $100 \mathrm{rpm}$ until the $\mathrm{pH}$ of the solution reached 7.0 \pm 0.2 . After settling for $30 \mathrm{~min}$, the resultant solids were separated from the solution by filtration with a $0.45-\mu \mathrm{m}$ membrane and washed with distilled water several times. After freeze-drying, pristine $\mathrm{Al}(\mathrm{OH})_{3}$ was obtained. The procedure of fabricating $\mathrm{Al}(\mathrm{OH})_{3}-\mathrm{F}_{\text {ads }}$ and $\mathrm{Al}(\mathrm{OH})_{3}-\mathrm{F}_{\text {coag }}$ was similar with that of pristine $\mathrm{Al}(\mathrm{OH})_{3}$, only with a slight modification. For preparing $\mathrm{Al}(\mathrm{OH})_{3}-\mathrm{F}_{\text {ads }}, 500 \mathrm{~mL}$ fluoride solution $(178 \mathrm{mM})$ was added into the beaker after the formation of $\mathrm{Al}(\mathrm{OH})_{3}$ solids under slow stirring at $50 \mathrm{rpm}$ for $20 \mathrm{~min}$; meanwhile, $\mathrm{pH}$ was maintained at $7.0 \pm 0.2$. For fabricating $\mathrm{Al}(\mathrm{OH})_{3}-\mathrm{F}_{\text {coag }}, 500 \mathrm{~mL}$ fluoride solution $(178 \mathrm{mM})$ was added into $500 \mathrm{~mL} \mathrm{AlCl}_{3} \cdot 6 \mathrm{H}_{2} \mathrm{O}$ solution $(20 \mathrm{mM})$ instead of $\mathrm{NaOH}$ solution. Then, $\mathrm{pH}$ was adjusted to $7.0 \pm 0.2$ with $\mathrm{NaOH}$ or $\mathrm{HNO}_{3}$. The two kinds of obtained fluoride-containing solid wastes were washed with distilled water for several times, freeze-dried, and then kept in an air-tight container for use.

\section{Batch adsorption experiments}

Equilibrium isotherm experiments were performed in 50$\mathrm{mL}$ polypropylene tubes with $\mathrm{As}(\mathrm{III})$ or $\mathrm{As}(\mathrm{V})$ solutions at an initial concentration in the range of $5-80 \mathrm{mg} / \mathrm{L}$ at room temperature and an adsorbent dosage of $0.02 \mathrm{~g} / \mathrm{L}$. During the adsorption, the $\mathrm{pH}$ of the solutions was maintained at 7 with $\mathrm{HNO}_{3}$ or $\mathrm{NaOH}$. The tubes were shaken at $30 \mathrm{rpm}$ on a utility rotary shaker for $24 \mathrm{~h}$. The liquid phase was then filtered by a $0.45-\mu \mathrm{m}$ membrane to analyze the concentrations of fluoride, $\mathrm{As}(\mathrm{III}), \mathrm{As}(\mathrm{V})$, and Al. The used adsorbents were freezedried for subsequent characterization.

The experiments of adsorption kinetics were conducted in $1,000 \mathrm{~mL} \mathrm{As}(\mathrm{III})$ or $\mathrm{As}(\mathrm{V})$ solution with an initial concentration of $10 \mathrm{mg} / \mathrm{L}$ and an adsorbent dosage of $0.02 \mathrm{~g} / \mathrm{L}$. Samples were taken at specified time intervals. The $\mathrm{pH}$ effect on the adsorption performance of the adsorbents was studied by the solution $\mathrm{pH}$ that varied in the range of 4-9 at an As(III) or $\mathrm{As}(\mathrm{V})$ initial concentration of $80 \mathrm{mg} / \mathrm{L}$.

\section{Extraction procedure}

Sequential extraction experiments were carried out to clarify the species distribution of $\mathrm{As}(\mathrm{III})$ or $\mathrm{As}(\mathrm{V})$ in different binding phases on used adsorbents. A three-step extraction was conducted to investigate the following three binding phases of arsenic (Shiowatana et al., 2001): (1) water-soluble As; (2) surface-adsorbed As; and (3) AlO-associated As. First, the extraction was carried out in sequence with ultrapure water, $0.5 \mathrm{M} \mathrm{NaHCO}_{3}$, and $0.1 \mathrm{M} \mathrm{NaOH}$ in polypropylene centrifuge tubes. These tubes were shaken for $24 \mathrm{~h}$ at $30 \mathrm{rpm}$. After each step of extraction, the samples were centrifuged at $3,000 \mathrm{rpm}$ for $2 \mathrm{~min}$. The obtained liquid phase was filtered through a $0.45-\mu \mathrm{m}$ membrane for As analysis. The three target phases of arsenic after each step of extraction corresponded to water-soluble As (Species-I), surfaceadsorbed As (Species-II), and AlO-associated As (Species-III).

\section{Analysis and characterization}

The concentrations of $\mathrm{Al}$ and As were analyzed by inductively coupled plasma-optical emission spectroscopy (OPTIMA 2000DA; PerkinElmer), and the detection limits were $0.8 \mu \mathrm{g} / \mathrm{L}$ for $\mathrm{Al}$ and $4 \mu \mathrm{g} / \mathrm{L}$ for As. The concentrations of fluoride were measured by a fluoride ion selective electrode (PF-1; Kangyi Instrument Ltd.) with the detection limit of $0.05 \mathrm{mg} / \mathrm{L}$. BET surface area $\left(\mathrm{S}_{\mathrm{BET}}\right)$ was determined by standard multipoint techniques of $\mathrm{N}_{2}$ adsorption with a BET analyzer (ASAP2000; Micromeritics). The $\zeta$-potential of samples was measured by a $\zeta$-potential analyzer (Zetasizer 2000; Malvern). XPS results were obtained by an ESCAlab-220i-XL spectrometer (Shimadzu) with monochromatic $\mathrm{Al} \mathrm{K} \alpha$ radiation $(225 \mathrm{~W}, 15 \mathrm{~mA}, 15 \mathrm{kV})$.

\section{Adsorption models}

Adsorption kinetic models. The following two kinetic models were used to clarify the adsorption process pseudo- 
first-order (Yuh-Shan, 2004) and pseudo-second-order (Ho and McKay, 1999) as described in Equations (1) and (2), respectively.

$$
\begin{gathered}
\log \left(\mathrm{q}_{\mathrm{e}}-\mathrm{q}\right)=\log \mathrm{q}_{\mathrm{e}}-\frac{\mathrm{k}_{1}}{2.303} \mathrm{t} \\
\frac{\mathrm{t}}{\mathrm{q}_{\mathrm{t}}}=\frac{1}{\mathrm{k}_{2} * \mathrm{q}_{\mathrm{e}}^{2}}+\frac{1}{\mathrm{q}_{\mathrm{e}}} \mathrm{t}
\end{gathered}
$$

where $\mathrm{q}$ and $\mathrm{q}_{\mathrm{e}}$ are the mass of metal adsorbed $(\mathrm{mg} / \mathrm{g})$ at time $\mathrm{t}$ and at equilibrium, respectively; $\mathrm{k}_{1}$ and $\mathrm{k}_{2}$ are the pseudofirst-order and pseudo-second-order kinetic rate constants.

Adsorption isotherm models. The Langmuir (Mckay et al., 1982) and Freundlich (Mckay et al., 1982) isotherms were used to analyze the adsorption of $\mathrm{As}(\mathrm{III}) / \mathrm{As}(\mathrm{V})$ on $\mathrm{Al}(\mathrm{OH})_{3}-\mathrm{F}$ solid wastes and pristine $\mathrm{Al}(\mathrm{OH})_{3}$ as represented by the equations below.

$$
\begin{aligned}
& \mathrm{q}_{\mathrm{e}}=\frac{\mathrm{q}_{\mathrm{m}} \mathrm{LC}_{\mathrm{e}}}{1+\mathrm{LC}_{e}} \\
& \mathrm{q}_{\mathrm{e}}=\mathrm{K}_{\mathrm{F}} \mathrm{C}_{\mathrm{e}}^{1 / \mathrm{n}}
\end{aligned}
$$

where $\mathrm{C}_{\mathrm{e}}$ and $\mathrm{q}_{\mathrm{e}}$ are the $\mathrm{As}(\mathrm{III})$ or $\mathrm{As}(\mathrm{V})$ concentration and the amount of $\mathrm{As}(\mathrm{III})$ or $\mathrm{As}(\mathrm{V})$ adsorbed at equilibrium; $\mathrm{q}_{\mathrm{m}}$ and $\mathrm{L}$ are Langmuir constants related to adsorption capacity and energy of adsorption; $\mathrm{K}_{\mathrm{f}}$ is the Freundlich constant; and $\mathrm{n}$ is an indication of surface heterogeneity and surface affinity of adsorption.

\section{Results and Discussion}

\section{Adsorbent characterization}

Table 1 illustrates $\mathrm{S}_{\mathrm{BET}}$, pore size, and $\mathrm{pH}_{\mathrm{PZC}}$ of pristine $\mathrm{Al}(\mathrm{OH})_{3}, \mathrm{Al}(\mathrm{OH})_{3}-\mathrm{F}_{\text {ads }}$, and $\mathrm{Al}(\mathrm{OH})_{3}-\mathrm{F}_{\text {coag. }} \mathrm{Al}(\mathrm{OH})_{3}$ showed the highest $\mathrm{S}_{\mathrm{BET}}$ of $195.6 \mathrm{~m}^{2} / \mathrm{g}$, which is slightly higher compared with $\mathrm{Al}(\mathrm{OH})_{3}-\mathrm{F}_{\text {ads }}$ and $\mathrm{Al}(\mathrm{OH})_{3}-\mathrm{F}_{\text {coag }}, 150.2$ and $123.7 \mathrm{~m}^{2} / \mathrm{g}$, respectively. This indicates that some pores of the pristine $\mathrm{Al}(\mathrm{OH})_{3}$ might be filled by fluoride. The average pore size of $\mathrm{Al}(\mathrm{OH})_{3}-\mathrm{F}_{\text {ads }}$ and $\mathrm{Al}(\mathrm{OH})_{3}-\mathrm{F}_{\text {coag }}$ also slightly declined compared with $\mathrm{Al}(\mathrm{OH})_{3}$, which provides further

Table 1. The Main Characteristics OF THE THREE ADSORBENTS

\begin{tabular}{lccc}
\hline & $\mathrm{Al}(\mathrm{OH})_{3}-\mathrm{F}_{\text {ads }}$ & $\mathrm{Al}(\mathrm{OH})_{3}-F_{\text {coag }}$ & $\mathrm{Al}(\mathrm{OH})_{3}$ \\
\hline Specific surface & 150.2 & 123.7 & 195.6 \\
$\quad$ area $\left(\mathrm{m}^{2} / \mathrm{g}\right)$ & & & \\
Pore size $(\mathrm{nm})$ & 16.6 & 16.6 & 18.0 \\
$\mathrm{pH}_{\mathrm{PZC}}$ & 7.4 & 8.0 & 8.0 \\
Ratio of F to Al $^{\text {Surface }}$ & & & \\
$\quad$ Bulk phase $^{\mathrm{b}}$ & $2.2: 1$ & $0.84: 1$ & $/^{\mathrm{c}}$ \\
\hline
\end{tabular}

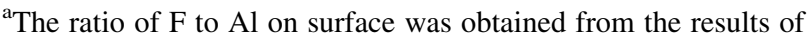
$\mathrm{X}$-ray photoelectron spectroscopy.

${ }^{\mathrm{b}}$ The ratio of $\mathrm{F}$ to $\mathrm{Al}$ in the bulk phase was obtained from the analysis of the concentration of $\mathrm{Al}$ and $\mathrm{F}$ before and after the fabrication of $\mathrm{Al}(\mathrm{OH})_{3}-\mathrm{F}_{\text {ads }}$ and $\mathrm{Al}(\mathrm{OH})_{3}-\mathrm{F}_{\text {coag. }}$.

${ }^{\mathrm{c}}$ There is no $\mathrm{F}$ on $\mathrm{Al}(\mathrm{OH})_{3}$ surfaces, and the ratio of $\mathrm{F}$ to $\mathrm{Al}$ is meaningless. evidence. The ratios of $\mathrm{F}$ to $\mathrm{Al}\left(\mathrm{R}_{\mathrm{F}: \mathrm{Al}}\right)$ on the surfaces of these adsorbents, as indicated by XPS analysis, were observed to be 2.2:1 and 0.8:1 for $\mathrm{Al}(\mathrm{OH})_{3}-\mathrm{F}_{\text {ads }}$ and $\mathrm{Al}(\mathrm{OH})_{3}-\mathrm{F}_{\text {coag }}$, respectively. However, the corresponding $\mathrm{R}_{\mathrm{F}: \mathrm{Al}}$ values in the bulk phases were both determined to be 1.0:1. This indicates that fluoride mainly exists on the surface of $\mathrm{Al}(\mathrm{OH})_{3}-\mathrm{F}_{\mathrm{ads}}$, whereas it is included within $\mathrm{Al}(\mathrm{OH})_{3}-\mathrm{F}_{\text {coag }}$.

\section{Adsorption kinetics}

Figure 1 illustrates the variation of adsorption density of $\mathrm{As}(\mathrm{III})$ and $\mathrm{As}(\mathrm{V})\left(q_{t}\right)$ onto pristine $\mathrm{Al}(\mathrm{OH})_{3}, \mathrm{Al}(\mathrm{OH})_{3}-\mathrm{F}_{\text {ads }}$, and $\mathrm{Al}(\mathrm{OH})_{3}-\mathrm{F}_{\text {coag }}$ as a function of adsorption time. It is clear that the incorporation of fluoride into $\mathrm{Al}(\mathrm{OH})_{3}$ inhibited the adsorption of both $\mathrm{As}(\mathrm{III})$ and $\mathrm{As}(\mathrm{V})$. The maximum $q_{t}$ value of $\mathrm{Al}(\mathrm{OH})_{3}$ is $8.4 \mathrm{mg} / \mathrm{g}$ for $\mathrm{As}(\mathrm{III})$ and $58.7 \mathrm{mg} / \mathrm{g}$ for $\mathrm{As}(\mathrm{V})$, respectively. By contrast, the maximum $q_{t, A s(I I I)}$ values of $\mathrm{Al}(\mathrm{OH})_{3}-\mathrm{F}_{\text {ads }}$ and $\mathrm{Al}(\mathrm{OH})_{3}-\mathrm{F}_{\text {coag }}$ are 4.3 and $6.5 \mathrm{mg} / \mathrm{g}$, respectively, being $49.3 \%$ and $22.9 \%$ lower compared with $\mathrm{Al}(\mathrm{OH})_{3}$. The adsorption of $\mathrm{As}(\mathrm{V})$ onto $\mathrm{Al}(\mathrm{OH})_{3}-\mathrm{F}_{\text {ads }}$ and $\mathrm{Al}(\mathrm{OH})_{3}-\mathrm{F}_{\text {coag }}$ is also lower compared with onto $\mathrm{Al}(\mathrm{OH})_{3}$. The maximum $q_{t, A s(V)}$ value is $30.6 \mathrm{mg} / \mathrm{g}$ for $\mathrm{Al}(\mathrm{OH})_{3}-\mathrm{F}_{\text {ads }}$ and $43.5 \mathrm{mg} / \mathrm{g}$ for $\mathrm{Al}(\mathrm{OH})_{3}-\mathrm{F}_{\text {coag }}$, which are $47.9 \%$ and $25.9 \%$ lower compared with $\mathrm{Al}(\mathrm{OH})_{3}$, respectively. Moreover, the incorporation of fluoride in $\mathrm{Al}(\mathrm{OH})_{3}-\mathrm{F}_{\mathrm{ads}}$ and

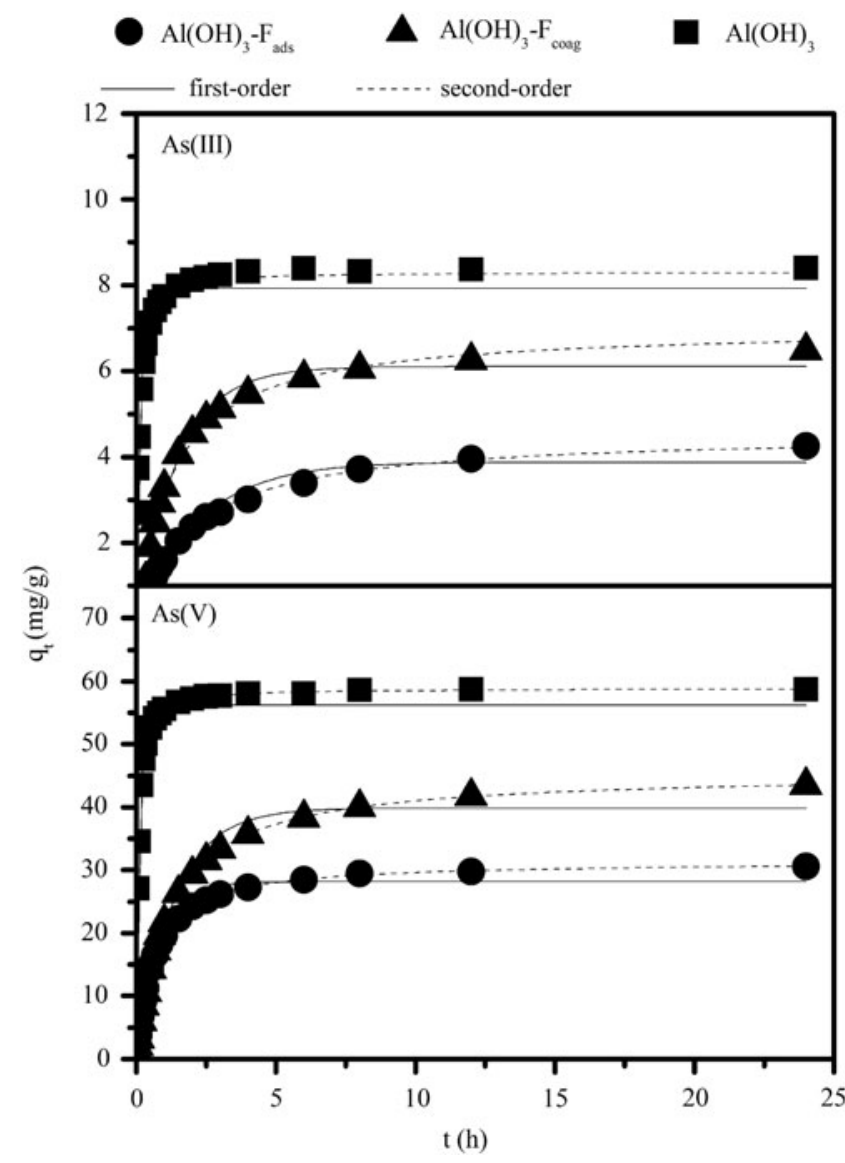

FIG. 1. The variation of adsorption density of As(III) and $\mathrm{As}(\mathrm{V})$ onto the three adsorbents with prolonged contact time (experimental conditions: initial concentration $=10 \mathrm{mg} / \mathrm{L}$, contact time $=24 \mathrm{~h}, \mathrm{pH}=7$, ionic strength $=0.01 \mathrm{M} \mathrm{NaNO}_{3}$, adsorbent dose $=0.02 \mathrm{~g} / \mathrm{L}$ ). 
Table 2. Kinetics Parameters of Pseudo-First-Order and Pseudo-Second-Order FOR As(III) AND As(V) ADSORPTION

\begin{tabular}{|c|c|c|c|c|c|c|c|}
\hline \multirow[b]{2}{*}{ Model } & \multirow[b]{2}{*}{ Parameter } & \multicolumn{2}{|c|}{$\mathrm{Al}(\mathrm{OH})_{3}-F_{a d s}$} & \multicolumn{2}{|c|}{$\mathrm{Al}(\mathrm{OH})_{3}-F_{\text {coag }}$} & \multicolumn{2}{|c|}{$\mathrm{Al}(\mathrm{OH})_{3}$} \\
\hline & & $A s(I I I)$ & $A s(V)$ & $A s(I I I)$ & $A s(V)$ & $A s(I I I)$ & $\operatorname{As}(V)$ \\
\hline \multirow{3}{*}{ Pseudo-first-order kinetic model } & $q_{e, \exp }(\mathrm{mg} / \mathrm{g})$ & 4.3 & 30.6 & 6.5 & 43.5 & 8.4 & 58.7 \\
\hline & $\begin{array}{l}k_{1}\left(\mathrm{~h}^{-1}\right) \\
q_{e, \text { cal }}(\mathrm{mg} / \mathrm{g})\end{array}$ & $\begin{array}{l}1.0 \\
3.9\end{array}$ & $\begin{array}{r}3.0 \\
28.2\end{array}$ & $\begin{array}{l}1.6 \\
6.1\end{array}$ & $\begin{array}{r}1.7 \\
39.8\end{array}$ & $\begin{array}{r}20.5 \\
7.9\end{array}$ & $\begin{array}{l}24.5 \\
56.2\end{array}$ \\
\hline & & 0.98 & 0.96 & 0.97 & 0.95 & 0.85 & 0.95 \\
\hline \multirow[t]{2}{*}{ Pseudo-second-order kinetic model } & $\begin{array}{l}k_{2}(\mathrm{mg} /[\mathrm{g} \cdot \mathrm{h}]) \\
q_{e, \text { cal }}(\mathrm{mg} / \mathrm{g})\end{array}$ & $\begin{array}{l}0.1 \\
4.6\end{array}$ & $\begin{array}{l}0.05 \\
31.3\end{array}$ & $\begin{array}{l}0.1 \\
7.0\end{array}$ & $\begin{array}{l}0.02 \\
45.5\end{array}$ & $\begin{array}{l}1.8 \\
8.3\end{array}$ & $\begin{array}{r}0.3 \\
58.9\end{array}$ \\
\hline & $R^{2}$ & 0.99 & 0.99 & 0.99 & 0.99 & 0.98 & 0.99 \\
\hline
\end{tabular}

$\mathrm{Al}(\mathrm{OH})_{3}-\mathrm{F}_{\text {coag }}$ slowed down the adsorption of $\mathrm{As}(\mathrm{III})$ and $\mathrm{As}(\mathrm{V})$ to some extent. Adsorption of As(III) and As(V) on $\mathrm{Al}(\mathrm{OH})_{3}$ was very fast and $\mathrm{q}_{t, A s(I I I)}$ and $\mathrm{q}_{t, A s(V)}$ almost reached equilibrium within $2 \mathrm{~h}$. However, it took about $12 \mathrm{~h}$ for $\mathrm{Al}(\mathrm{OH})_{3}-\mathrm{F}_{\text {ads }}$ and $\mathrm{Al}(\mathrm{OH})_{3}-\mathrm{F}_{\text {coag }}$ to reach the adsorption equilibrium of $\mathrm{As}(\mathrm{III})$ and $\mathrm{As}(\mathrm{V})$.

To further illustrate the effect of fluoride on the adsorption of arsenic, the experimental data were respectively fitted by pseudo-first-order and pseudo-second-order kinetic models. Table 2 summarizes the obtained parameters and regression coefficient $\left(R^{2}\right)$. The fitted curves using these kinetic equations are plotted in Fig. 1. As indicated by higher $R^{2}$, the pseudo-second-order model better fits the adsorption of arsenic onto these adsorbents than the pseudo-first-order model. The value of $k_{2} q_{e}$ in the pseudo-second-order model is an indicator of the adsorption rate. The calculated $k_{2} q_{e}$ values of $\mathrm{As}(\mathrm{III})$ adsorption onto $\mathrm{Al}(\mathrm{OH})_{3}-\mathrm{F}_{\mathrm{ads}}, \mathrm{Al}(\mathrm{OH})_{3^{-}}$ $\mathrm{F}_{\text {coag }}$, and $\mathrm{Al}(\mathrm{OH})_{3}$ are $0.5,0.7$, and $15.0 / \mathrm{h}$, respectively. The adsorption of $\mathrm{As}(\mathrm{V})$ on the adsorbents yields higher $k_{2} q_{e}$ values, being $1.6,0.9$, and $17.7 / \mathrm{h}$, respectively, which is related to the faster adsorption rate of $\mathrm{As}(\mathrm{V})$ compared with As(III) adsorption. The different adsorption rate between $\mathrm{As}(\mathrm{III})$ and $\mathrm{As}(\mathrm{V})$ is attributed to the difference of the electrostatic interactions between them and these adsorbents. The $\mathrm{pH}_{\mathrm{PZC}}$ values of $\mathrm{Al}(\mathrm{OH})_{3}-\mathrm{F}_{\text {ads }}, \mathrm{Al}(\mathrm{OH})_{3}-\mathrm{F}_{\text {coag }}$, and $\mathrm{Al}(\mathrm{OH})_{3}$ were determined to be 7.4, 8.0, and 8.0, respectively. Hence, the three adsorbents have positive surfaces at $\mathrm{pH} 7$ in this study. As(III) exists as the neutral species $\mathrm{H}_{3} \mathrm{AsO}_{3}$ at $\mathrm{pH} 7$, whereas $\mathrm{As}(\mathrm{V})$ is predominantly in the negatively charged species $\mathrm{H}_{2} \mathrm{AsO}_{4}{ }^{-}$and $\mathrm{HAsO}_{4}{ }^{2-}$. Hence, the stronger electrostatic attraction between $\mathrm{As}(\mathrm{V})$ and the adsorbent surfaces leads to the faster and more significant adsorption of As(V) on these adsorbents.

\section{Adsorption isotherm}

Figure 2 illustrates the adsorption isotherm of $\mathrm{As}(\mathrm{III})$ and $\mathrm{As}(\mathrm{V})$ onto $\mathrm{Al}(\mathrm{OH})_{3}, \mathrm{Al}(\mathrm{OH})_{3}-\mathrm{F}_{\text {ads }}$, and $\mathrm{Al}(\mathrm{OH})_{3}-\mathrm{F}_{\text {coag. The }}$ maximum adsorption capacities $\left(\mathrm{q}_{\mathrm{e}, \exp }\right)$ of $\mathrm{As}(\mathrm{III})$ and $\mathrm{As}(\mathrm{V})$ onto these three adsorbents are listed in Table 3. The results also show that the incorporation of fluoride into $\mathrm{Al}(\mathrm{OH})_{3}$ through either adsorption or coagulation greatly decreased its adsorption capacity toward $\mathrm{As}(\mathrm{III})$ and $\mathrm{As}(\mathrm{V})$. Compared with $\mathrm{Al}(\mathrm{OH})_{3}-\mathrm{F}_{\text {coag }}, \mathrm{Al}(\mathrm{OH})_{3}-\mathrm{F}_{\text {ads }}$ has a higher $\mathrm{q}_{\mathrm{e} \text {,exp }}$, which indicates that more adsorption sites are available on the $\mathrm{Al}(\mathrm{OH})_{3}-\mathrm{F}_{\text {ads }}$ surface than on the $\mathrm{Al}(\mathrm{OH})_{3}-\mathrm{F}_{\text {coag }}$ surface. This was confirmed by $\mathrm{S}_{\mathrm{BET}}$ analysis. The $\mathrm{S}_{\mathrm{BET}}$ of $\mathrm{Al}(\mathrm{OH})_{3}-\mathrm{F}_{\mathrm{ads}}$ and $\mathrm{Al}(\mathrm{OH})_{3}-\mathrm{F}_{\text {coag }}$ are 150.2 and $123.7 \mathrm{~m}^{2} / \mathrm{g}$, respectively.

Table 3 illustrates the fitted parameters for the Langmuir and Freundlich models. The Langmuir model has a higher $R^{2}$ value, which means that it is more suitable to describe the adsorption of As(III) and As(V) than the Freundlich model. The Langmuir isotherm is based on the assumption that monolayer surface coverage limits the adsorption due to surface saturation (Guo et al., 2007). The maximum adsorption capacity calculated by the Langmuir model $\left(\mathrm{Q}_{\text {max,cal }}\right)$ of As(III) and $\mathrm{As}(\mathrm{V})$ on both $\mathrm{Al}(\mathrm{OH})_{3}-\mathrm{F}_{\text {ads }}$ and $\mathrm{Al}(\mathrm{OH})_{3}-\mathrm{F}_{\text {coag }}$ is lower than those on $\mathrm{Al}(\mathrm{OH})_{3}$. The introduction of negatively charged

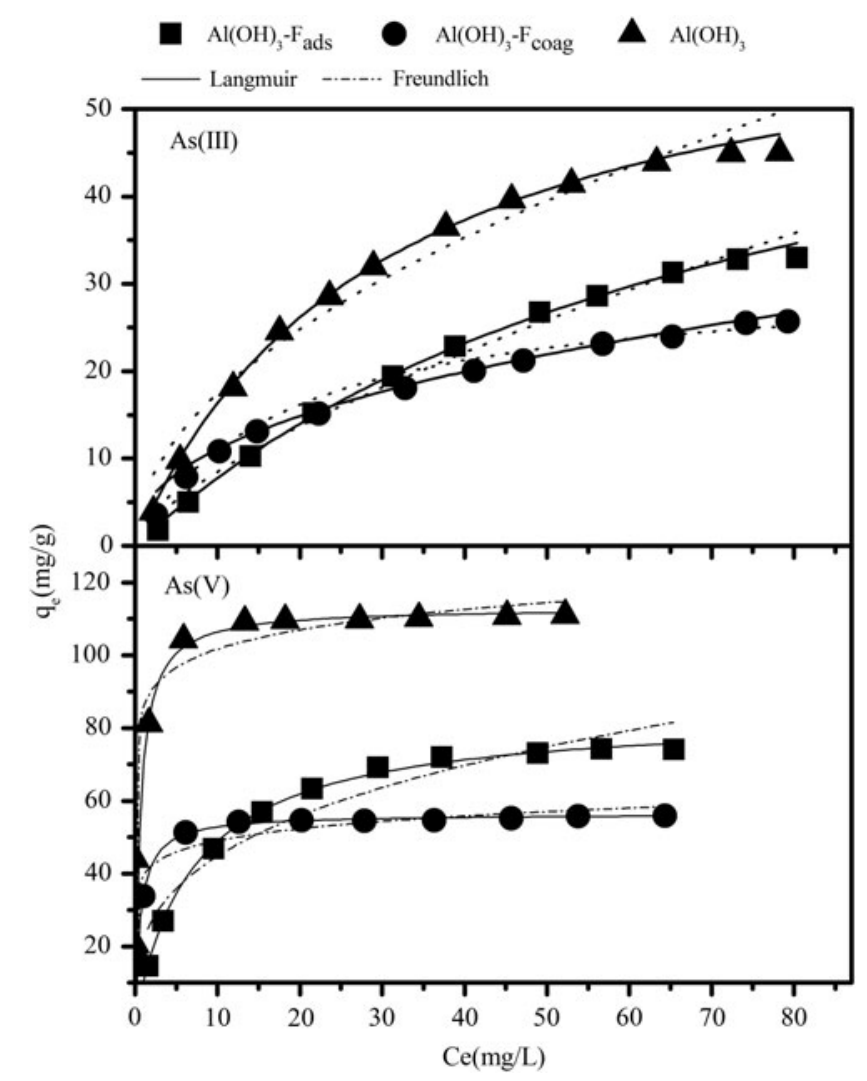

FIG. 2. Adsorption isotherms of $\mathrm{As}(\mathrm{III})$ and $\mathrm{As}(\mathrm{V})$ onto the three adsorbents (experimental conditions: contact time $=24 \mathrm{~h}, \mathrm{pH}=7$, ionic strength $=0.01 \mathrm{M} \mathrm{NaNO}_{3}$, adsorbent dose $=0.02 \mathrm{~g} / \mathrm{L}$ ). 
Table 3. Langmuir and Freundlich Parameters for the Adsorption of As(III) And As(V) Onto the Three Adsorbents

\begin{tabular}{|c|c|c|c|c|c|c|c|}
\hline \multirow[b]{2}{*}{ Model } & \multirow[b]{2}{*}{ Parameter } & \multicolumn{2}{|c|}{$\mathrm{Al}(\mathrm{OH})_{3}-F_{a d s}$} & \multicolumn{2}{|c|}{$\mathrm{Al}(\mathrm{OH})_{3}-F_{\text {coag }}$} & \multicolumn{2}{|c|}{$\mathrm{Al}(\mathrm{OH})_{3}$} \\
\hline & & $A s(I I I)$ & $A s(V)$ & $A s(I I I)$ & $A s(V)$ & $A s(I I I)$ & $A s(V)$ \\
\hline & $q_{e, \exp }(\mathrm{mg} / \mathrm{g})$ & 33.0 & 74.1 & 25.7 & 55.9 & 45.0 & 111.0 \\
\hline Langmuir model & $\begin{array}{l}Q_{\max , c a l}(\mathrm{mg} / \mathrm{g}) \\
L(\mathrm{~L} / \mathrm{mg}) \\
R^{2}\end{array}$ & $\begin{array}{c}47.9 \\
0.01 \\
0.99\end{array}$ & $\begin{array}{c}84.0 \\
1.3 \\
0.99\end{array}$ & $\begin{array}{c}31.0 \\
0.06 \\
0.99\end{array}$ & $\begin{array}{c}56.3 \\
1.5 \\
0.98\end{array}$ & $\begin{array}{c}65.1 \\
0.03 \\
0.99\end{array}$ & $\begin{array}{r}113.0 \\
1.6 \\
0.99\end{array}$ \\
\hline Freundlich model & $\begin{array}{l}F \\
N \\
R^{2}\end{array}$ & $\begin{array}{l}1.7 \\
1.4 \\
0.97\end{array}$ & $\begin{array}{c}21.5 \\
3.1 \\
0.93\end{array}$ & $\begin{array}{l}4.2 \\
2.4 \\
0.91\end{array}$ & $\begin{array}{c}39.5 \\
10.6 \\
0.92\end{array}$ & $\begin{array}{l}5.4 \\
2.0 \\
0.95\end{array}$ & $\begin{array}{r}85.8 \\
13.6 \\
0.94\end{array}$ \\
\hline
\end{tabular}

fluoride into $\mathrm{Al}(\mathrm{OH})_{3}$ not only occupies the surface sites but also inhibits the adsorption of $\mathrm{As}(\mathrm{III})$ and $\mathrm{As}(\mathrm{V})$. In addition, the $L$ values of $\mathrm{Al}(\mathrm{OH})_{3}-\mathrm{F}_{\text {ads }}, \mathrm{Al}(\mathrm{OH})_{3}-\mathrm{F}_{\text {coag }}$, and $\mathrm{Al}(\mathrm{OH})_{3}$ were calculated to be $1.3,1.5$, and $1.6 \mathrm{~L} / \mathrm{mg}$ for $\mathrm{As}(\mathrm{V})$ and 0.01 , 0.06 , and $0.03 \mathrm{~L} / \mathrm{mg}$ for $\mathrm{As}(\mathrm{III})$, and this indicated the stronger affinity of these adsorbents toward $\mathrm{As}(\mathrm{V})$ than that toward As(III).

\section{Effect of $\mathrm{pH}$ on the adsorption of $A s(I I I)$ and $A s(V)$}

Figure 3 illustrates the adsorption density of As(III) and $\mathrm{As}(\mathrm{V})$ onto these adsorbents over a wide $\mathrm{pH}$ range from 4 to 9. The adsorption of $\mathrm{As}(\mathrm{III})$ onto $\mathrm{Al}(\mathrm{OH})_{3}-\mathrm{F}_{\text {ads }}, \mathrm{Al}(\mathrm{OH})_{3^{-}}$ $\mathrm{F}_{\text {coag }}$, and $\mathrm{Al}(\mathrm{OH})_{3}$ declines with increasing $\mathrm{pH}$ in $\mathrm{pH}$ ranges from 4 to 6 and from 7 to 9. At $\mathrm{pH}$ below 8, nonionic $\mathrm{H}_{3} \mathrm{AsO}_{3}$ is the dominant As(III) species, and the adsorption of As(III)

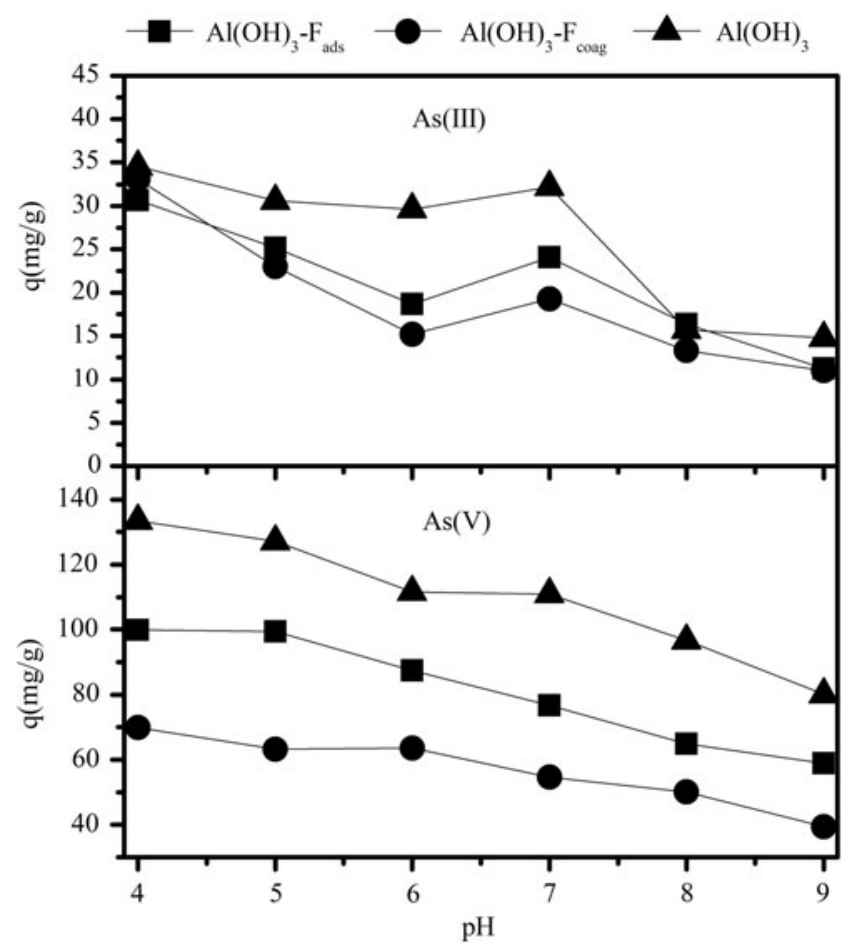

FIG. 3. Uptake of $\mathrm{As}(\mathrm{III})$ and $\mathrm{As}(\mathrm{V})$ onto the three adsorbents in the $\mathrm{pH}$ range 4-9 (experimental conditions: initial concentration $=80 \mathrm{mg} / \mathrm{L}$, contact time $=24 \mathrm{~h}$, ionic strength $=0.01 \mathrm{M} \mathrm{NaNO}$, adsorbent doses $=0.02 \mathrm{~g} / \mathrm{L}$ ). was mainly attributed to the Van der Waal force (Lin and Wu, 2001) and the formation of an inner sphere surface complex (Ona-Nguema et al., 2005). At elevated $\mathrm{pH}$ above 7 , the dissociation of $\mathrm{H}_{3} \mathrm{AsO}_{3}$ to anionic $\mathrm{H}_{2} \mathrm{AsO}_{3}{ }^{-}$occurred, and the adsorption of As(III) onto the positive surfaces was improved due to specific bonding and electrostatic interaction. At $\mathrm{pH}$ above 8 , these adsorbents showed negatively charged surfaces, and the adsorption of negative As(III) was inhibited accordingly.

The uptake of $\mathrm{As}(\mathrm{V})$ on these adsorbents also declines with increasing $\mathrm{pH}$. Results of MINTEQ modeling indicate that $\mathrm{As}(\mathrm{V})$ mainly exists in the form of $\mathrm{H}_{2} \mathrm{AsO}_{4}{ }^{-}$in the $\mathrm{pH}$ range from 3 to 7 and $\mathrm{HAsO}_{4}{ }^{2-}$ is the dominant species at $\mathrm{pH}>7$. On the other hand, the point of zero charge $\left(\mathrm{pH}_{\mathrm{pzc}}\right)$ was determined to be 7.4, 8.0, and 8.0 for $\mathrm{Al}(\mathrm{OH})_{3}-\mathrm{F}_{\text {ads }}, \mathrm{Al}(\mathrm{OH})_{3}-$ $\mathrm{F}_{\text {coag }}$, and $\mathrm{Al}(\mathrm{OH})_{3}$. At $\mathrm{pH}$ below these $\mathrm{pH}_{\mathrm{pzc}}$, these adsorbents showed positive surfaces as described in Equation (5). The electrostatic attraction between the positively charged sites and $\mathrm{As}(\mathrm{V}), \mathrm{H}_{2} \mathrm{AsO}_{4}{ }^{-}$, and $\mathrm{HAsO}_{4}{ }^{2-}$ is stronger at a lower $\mathrm{pH}$ which, in turn, results in a higher $\mathrm{As}(\mathrm{V})$ uptake. At $\mathrm{pH}$ above $\mathrm{pH}_{\mathrm{PZC}}$, these adsorbents exhibited negative surfaces as described in Equation (6) and the repulsive forces inhibited the adsorption of negative $\mathrm{As}(\mathrm{V})$ species thereafter.

$$
\begin{gathered}
\equiv \mathrm{S}-\mathrm{OH}+\mathrm{H}^{+} \rightarrow \equiv{\mathrm{S}-\mathrm{OH}_{2}^{+}}^{+} \\
\equiv \mathrm{S}-\mathrm{OH}+\mathrm{OH}^{-} \rightarrow \equiv \mathrm{S}-\mathrm{O}^{-}+\mathrm{H}_{2} \mathrm{O}
\end{gathered}
$$

\section{Proposed mechanisms involved in the adsorption of $A s(I I I)$ and $A s(V)$}

The variation of solution $\mathrm{pH}$ during the adsorption of $\mathrm{As}(\mathrm{III})$ and $\mathrm{As}(\mathrm{V})$ onto these three adsorbents was monitored and the results are shown in Fig. 4. A significant decrease in solution $\mathrm{pH}$ during $\mathrm{As}(\mathrm{III})$ and $\mathrm{As}(\mathrm{V})$ adsorption as a function of adsorption time was observed. The $\mathrm{pH}$ of the solution remained unchanged after $50 \mathrm{~min}$ for $\mathrm{As}(\mathrm{III})$ and $5 \mathrm{~h}$ for $\mathrm{As}(\mathrm{V})$. To make the variation of $\mathrm{pH}$ with contact time more obvious, the results were only shown up to $50 \mathrm{~min}$ for As(III) and $5 \mathrm{~h}$ for $\mathrm{As}(\mathrm{V})$.

The decrease of $\mathrm{pH}$ during $\mathrm{As}(\mathrm{III})$ and $\mathrm{As}(\mathrm{V})$ adsorption can be explained by the deprotonation of the $\mathrm{H}_{n} \mathrm{AsO}_{4}{ }^{(3-n)-}$ or $\mathrm{H}_{n} \mathrm{AsO}_{3}{ }^{(3-n)-}(n=1,2,3)$. During the adsorption process, the protonated sites on the surface will adsorb negatively charged $\mathrm{As}(\mathrm{III})$ and $\mathrm{As}(\mathrm{V})$ species. This will shift the 

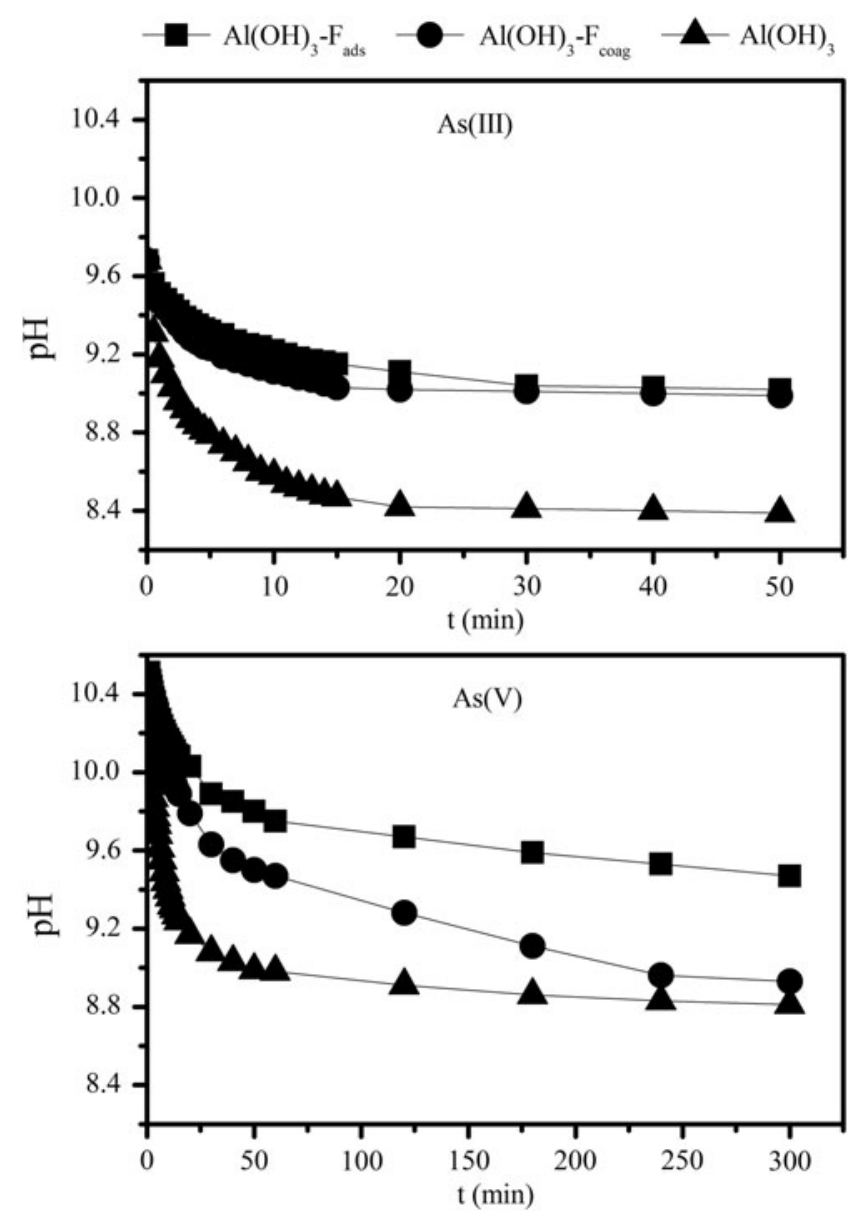

FIG. 4. Solution $\mathrm{pH}$ variation during the adsorption of $\mathrm{As}(\mathrm{III}) / \mathrm{As}(\mathrm{V})$ by the three adsorbents with prolonged time (experimental conditions: initial concentration $=80 \mathrm{mg} / \mathrm{L}$, contact time $=24 \mathrm{~h}$, ionic strength $=0.01 \mathrm{M} \mathrm{NaNO}_{3}$, adsorbent dose $=0.02 \mathrm{~g} / \mathrm{L})$.

equilibrium of deprotonation and release more hydrogen ions, thus leading to the reduction of $\mathrm{pH}$. A longer time is required to achieve equilibrium for $\mathrm{As}(\mathrm{V})$, and the equilibrium $\mathrm{pH}$ is also lower compared with As(III). This further suggests that the adsorption of As(III) and As(V) may be dominated by different mechanisms. Sequential extraction experiments were conducted to provide quantitative information on the distribution of arsenic [i.e., As(III) and As(V)] in three different binding phases on the three adsorbents, and the ratios of the arsenic species are shown in Fig. 5. The water-solute fraction (SpeciesI) is the dominant $\mathrm{As}(\mathrm{III})$ species on $\mathrm{Al}(\mathrm{OH})_{3}-\mathrm{F}_{\text {ads }}, \mathrm{Al}(\mathrm{OH})_{3}$ $\mathrm{F}_{\text {coag }}$, and $\mathrm{Al}(\mathrm{OH})_{3}$ and its ratios are $51.3 \%, 42.2 \%$, and $47.3 \%$, respectively. By contrast, the ratios of $\mathrm{As}(\mathrm{III})$ species binding to -OAl (Species-III) are much lower, being 7.8\%, 20.0\%, and $14.6 \%$ for $\mathrm{Al}(\mathrm{OH})_{3}-\mathrm{F}_{\text {ads }}, \mathrm{Al}(\mathrm{OH})_{3}-\mathrm{F}_{\text {coag }}$, and $\mathrm{Al}(\mathrm{OH})_{3}$, respectively. This indicates that the incorporation of As(III) onto $\mathrm{Al}(\mathrm{OH})_{3}-\mathrm{F}_{\text {ads }}, \mathrm{Al}(\mathrm{OH})_{3}-\mathrm{F}_{\text {coag }}$, and $\mathrm{Al}(\mathrm{OH})_{3}$ mainly exists in a soluble form.

However, the smaller variation of $\mathrm{pH}$ values for $\mathrm{Al}(\mathrm{OH})_{3-}$ $\mathrm{F}_{\text {ads }}$ and $\mathrm{Al}(\mathrm{OH})_{3}-\mathrm{F}_{\text {coag }}$ indicated that other processes apart from complexation may take place in the adsorption of As(V), such as ion exchange (Liu et al., 2012), as described in Equations (7) and (8).
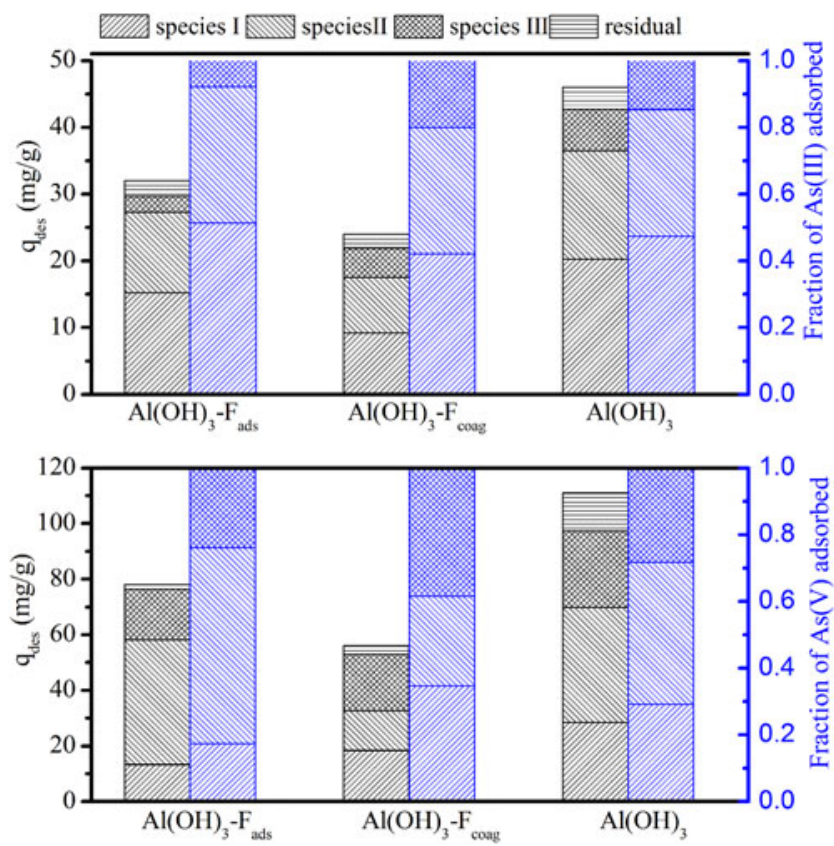

FIG. 5. The content and ratios of $\mathrm{As}(\mathrm{III}) / \mathrm{As}(\mathrm{V})$ in different binding species within the three adsorbents.

$$
\begin{aligned}
& \equiv \mathrm{S}-\mathrm{F}^{-}+\mathrm{H}_{n} \mathrm{AsO}_{4}^{(3-n)-} \rightarrow \\
& \equiv \mathrm{S}_{-} \mathrm{H}_{n} \mathrm{AsO}_{4}^{(3-n)-}+\mathrm{F}^{-}(n=1,2) \\
& \equiv \mathrm{S}-\mathrm{OH}-\mathrm{Na}-\mathrm{F}^{-}{ }_{\text {(solid) }}+\mathrm{H}_{n} \mathrm{AsO}_{4}^{(3-n)-} \rightarrow \\
& \equiv \mathrm{S}-\mathrm{OH}-\mathrm{Na}-\mathrm{H}_{n} \mathrm{AsO}_{4}{ }^{(3-n)-}+\mathrm{F}^{-}(n=1,2)
\end{aligned}
$$

For the binding phases of $\mathrm{As}(\mathrm{V}), \mathrm{Al}(\mathrm{OH})_{3}-\mathrm{F}_{\text {coag }}$ has the highest percentage of $34.7 \%$ for the soluble form (Species-I). Its percentage of Species-II and Species-III is $26.9 \%$ and $38.4 \%$, respectively. The As(V) species binding to -OAl, expressed as Species-III, bond strongly with the solid phase and hardly released into the solution. A slight difference is observed between Species-I and Species-III for $\mathrm{As}(\mathrm{V})$ loaded on $\mathrm{Al}(\mathrm{OH})_{3}-\mathrm{F}_{\text {coag }}$, which indicates that both complexation and electrostatic attraction play important roles in $\mathrm{As}(\mathrm{V})$ removal by $\mathrm{Al}(\mathrm{OH})_{3^{-}}$ $\mathrm{F}_{\text {coag. }}$. Compared with $\mathrm{Al}(\mathrm{OH})_{3}-\mathrm{F}_{\text {coag }}$, the ratios of Species-III on $\mathrm{Al}(\mathrm{OH})_{3}-\mathrm{F}_{\text {ads }}$ and $\mathrm{Al}(\mathrm{OH})_{3}$ are much lower, being $23.9 \%$ and $28.2 \%$, respectively. This means that the formation of an As-O complex is of more importance for $\mathrm{As}(\mathrm{V})$ removal by $\mathrm{Al}(\mathrm{OH})_{3^{-}}$ $\mathrm{F}_{\text {coag }}$ than by the other two adsorbents. $\mathrm{As}(\mathrm{V})$ on $\mathrm{Al}(\mathrm{OH})_{3}-\mathrm{F}_{\text {ads }}$ and $\mathrm{Al}(\mathrm{OH})_{3}$ is mainly extracted in the surface-adsorbed fraction (Species-II) at $58.7 \%$ and $42.6 \%$, respectively. Fluoride is mostly adsorbed on the surface of the adsorbent $\mathrm{Al}(\mathrm{OH})_{3}-\mathrm{F}_{\mathrm{ads}}$ in the removal of fluoride by adsorption. Thus, more $\mathrm{F}^{-}$on the surface of $\mathrm{Al}(\mathrm{OH})_{3}-\mathrm{F}_{\text {ads }}$ could exchange with the negatively charged anions $\mathrm{H}_{2} \mathrm{AsO}_{4}{ }^{-}$and $\mathrm{HAsO}_{4}{ }^{2-}$ compared with $\mathrm{Al}(\mathrm{OH})_{3}-\mathrm{F}_{\text {coag }}$ in the adsorption of $\mathrm{As}(\mathrm{V})$.

After discussing the adsorptive properties of $\mathrm{Al}(\mathrm{OH})_{3}-\mathrm{F}_{\mathrm{ads}}$ and $\mathrm{Al}(\mathrm{OH})_{3}-\mathrm{F}_{\text {coag }}$, it is necessary to address whether fluoride and $\mathrm{Al}$ are leached during the adsorption process. The concentration of leached fluoride in the solution was measured during adsorption of $\mathrm{As}(\mathrm{III})$ and $\mathrm{As}(\mathrm{V})$, and the results are illustrated in Fig. 6a. The maximum concentration of released 

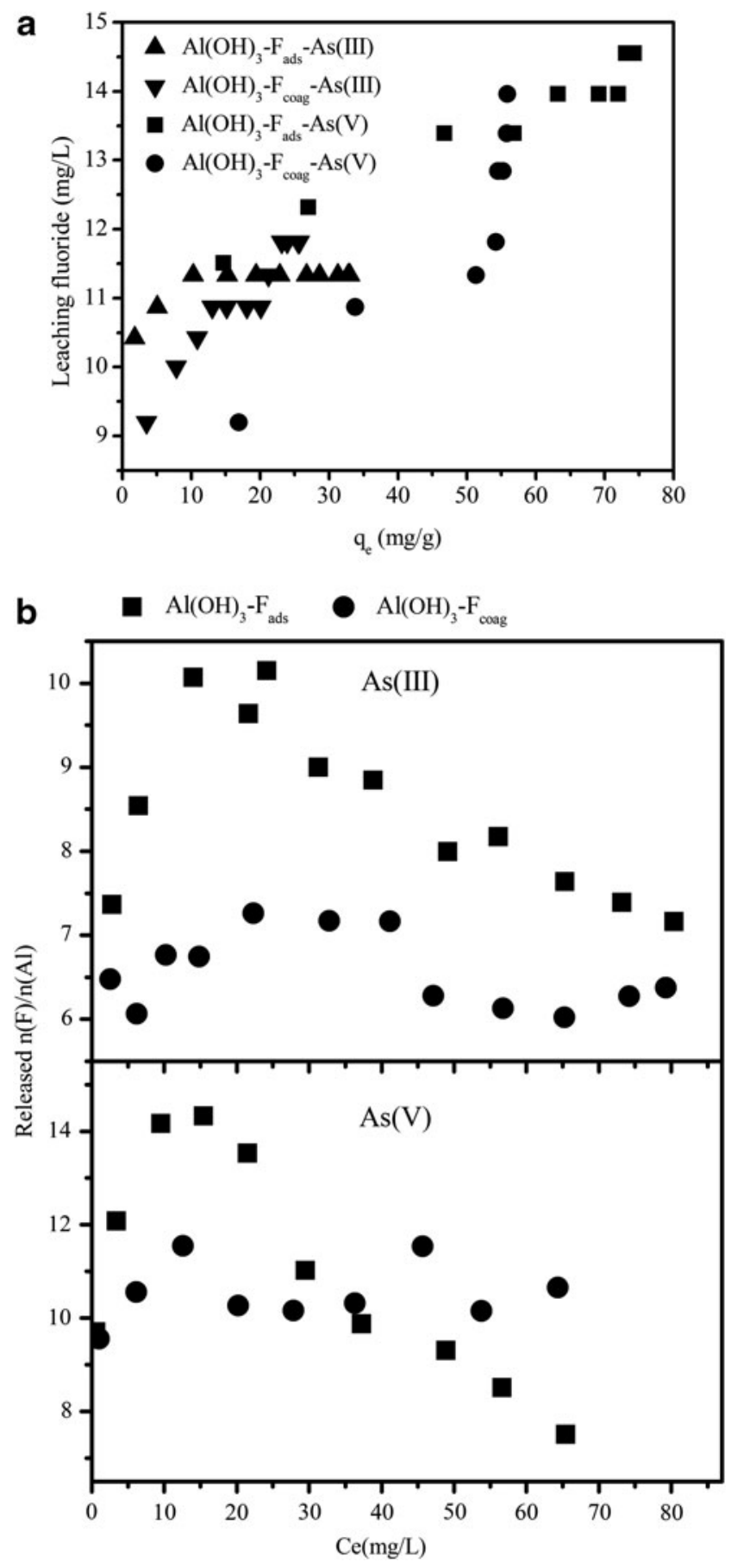

FIG. 6. The release of fluoride and $\mathrm{Al}$ from $\mathrm{Al}(\mathrm{OH})_{3}-\mathrm{F}_{\text {ads }}$ and $\mathrm{Al}(\mathrm{OH})_{3}-\mathrm{F}_{\text {coag }}$ during adsorption of $\mathrm{As}(\mathrm{III}) / \mathrm{As}(\mathrm{V})$. (a) The concentrations of leaching fluoride; (b) the ratios of released fluoride to $\mathrm{Al}$.

fluoride is $11.3 \mathrm{mg} / \mathrm{L}$ in the adsorption of $\mathrm{As}(\mathrm{III})$ by $\mathrm{Al}(\mathrm{OH})_{3^{-}}$ $\mathrm{F}_{\mathrm{ads}}, 11.8 \mathrm{mg} / \mathrm{L}$ in the adsorption of $\mathrm{As}(\mathrm{III})$ by $\mathrm{Al}(\mathrm{OH})_{3}-\mathrm{F}_{\text {coag }}$, $14.6 \mathrm{mg} / \mathrm{L}$ in the adsorption of $\mathrm{As}(\mathrm{V})$ by $\mathrm{Al}(\mathrm{OH})_{3}-\mathrm{F}_{\mathrm{ads}}$, and $14.0 \mathrm{mg} / \mathrm{L}$ in the adsorption of $\mathrm{As}(\mathrm{V})$ by $\mathrm{Al}(\mathrm{OH})_{3}-\mathrm{F}_{\text {coag }}$. These are all below the Chinese Class-II industrial discharge standard for fluoride $(<20 \mathrm{mg} / \mathrm{L})$. The ratio of released fluoride to $\mathrm{Al}\left(\mathrm{R}_{\mathrm{F}: \mathrm{Al}}\right)$ in molar terms during $\mathrm{As}(\mathrm{V})$ adsorption is higher than that during As(III) adsorption, as shown in Fig. 6b. Due to the hard-hard combination, in agreement with the soft-hard acid base concept, the presence of fluoride ion can produce changes in the concentration of $\mathrm{Al}$ in water. For $\mathrm{Al}(\mathrm{OH})_{3}-\mathrm{F}_{\mathrm{ads}}$, the value of $\mathrm{R}_{\mathrm{F}: \mathrm{Al}}$ first increases and then decreases with the increasing equilibrium concentration of As(III)/As(V). This suggests that the fluoride ions compete for the active sites with negatively charged anions, $\mathrm{H}_{2} \mathrm{AsO}_{4}{ }^{-}$ and $\mathrm{HAsO}_{4}{ }^{2-}$. The variation of $\mathrm{R}_{\mathrm{F}: \mathrm{Al}}$ for $\mathrm{Al}(\mathrm{OH})_{3}-\mathrm{F}_{\text {coag }}$ is small compared with $\mathrm{Al}(\mathrm{OH})_{3}-\mathrm{F}_{\mathrm{ads}}$. This indicates that the fluoride mainly exists on the surface of $\mathrm{Al}(\mathrm{OH})_{3}-\mathrm{F}_{\mathrm{ads}}$, whereas it is solidified within $\mathrm{Al}(\mathrm{OH})_{3}-\mathrm{F}_{\text {coag }}$.

The XPS binding energy and the ratios of main elements on the surfaces of different adsorbents before and after adsorbing arsenic were obtained from XPS analysis. As shown in Fig. 7a, the adsorption of $\mathrm{As}(\mathrm{III})$ and $\mathrm{As}(\mathrm{V})$ shows little influence on the binding energy of $\mathrm{O} 1 \mathrm{~s}$ within $\mathrm{Al}(\mathrm{OH})_{3}-\mathrm{F}_{\text {ads }}$ and $\mathrm{Al}(\mathrm{OH})_{3}$, and the interaction between $\mathrm{O}$ atoms and arsenic is assumed to be weak. Interestingly, the binding energy of $\mathrm{O} 1 \mathrm{~s}$ within $\mathrm{Al}(\mathrm{OH})_{3}-\mathrm{F}_{\text {coag }}$ slightly shifts from 531.3 to $531.7 \mathrm{eV}$ after adsorbing As(III) and to $531.8 \mathrm{eV}$ after adsorbing $\mathrm{As}(\mathrm{V})$. This might be attributed to the decreased electron density in the $\mathrm{O} 1 \mathrm{~s}$ shell owing to the combination of As(III) and As(V) with the interfacial $-\mathrm{OH}$ groups (Mohan and Pittman, 2007). Hence, it is further proven that that the formation of surface complexes plays a more dominant role in the adsorption of arsenic by $\mathrm{Al}(\mathrm{OH})_{3}-\mathrm{F}_{\text {coag }}$ than that by $\mathrm{Al}(\mathrm{OH})_{3}-\mathrm{F}_{\text {ads }}$ and $\mathrm{Al}(\mathrm{OH})_{3}$.

XPS spectra in Fig. 7b shows little variation in the binding energy of $\mathrm{F} 1 \mathrm{~s}$ after the adsorption of $\mathrm{As}(\mathrm{III})$ for both $\mathrm{Al}(\mathrm{OH})_{3^{-}}$ $\mathrm{F}_{\text {ads }}$ and $\mathrm{Al}(\mathrm{OH})_{3}-\mathrm{F}_{\text {coag }}$, and it is suggested that elemental $\mathrm{F}$ rarely participates in the removal of As(III). The adsorption of $\mathrm{As}(\mathrm{V})$ onto $\mathrm{Al}(\mathrm{OH})_{3}-\mathrm{F}_{\text {ads }}$ contributes to the shift of the binding energy of $\mathrm{F} 1 \mathrm{~s}$ from 685.0 to $685.4 \mathrm{eV}$, and this is attributed to the stronger binding between fluoride and $\mathrm{Al}(\mathrm{OH})_{3}-\mathrm{F}_{\mathrm{ads}}$ surfaces. On the other hand, the content of F1s on surfaces also shows different trends after the adsorption of $\mathrm{As}(\mathrm{III})$ and $\mathrm{As}(\mathrm{V})$. After adsorbing As(III), the content of F1s slightly decreases from $12.9 \%$ to $10.4 \%$ for $\mathrm{Al}(\mathrm{OH})_{3}-\mathrm{F}_{\text {coag }}$, whereas it significantly decreases from $28.7 \%$ to $14.5 \%$ for $\mathrm{Al}(\mathrm{OH})_{3}-\mathrm{F}_{\text {ads. }}$. The adsorption of $\mathrm{As}(\mathrm{V})$ also contributes to a sharp decrease of $\mathrm{F} 1 \mathrm{~s}$ content from $28.7 \%$ to $7.2 \%$ for $\mathrm{Al}(\mathrm{OH})_{3}-\mathrm{F}_{\text {ads }}$ and to an insignificant change from $12.9 \%$ to $10 \%$ for $\mathrm{Al}(\mathrm{OH})_{3}-\mathrm{F}_{\text {coag. This }}$ further demonstrates that fluoride mainly exists on the surface of $\mathrm{Al}(\mathrm{OH})_{3}-\mathrm{F}_{\text {ads }}$, whereas it is solidified within $\mathrm{Al}(\mathrm{OH})_{3}-\mathrm{F}_{\text {coag }}$ through the formation of inner-sphere Al-F complexes. Moreover, it can be concluded that more $\mathrm{F}^{-}$on the surface of $\mathrm{Al}(\mathrm{OH})_{3}-\mathrm{F}_{\text {ads }}$ exchanges with the negatively charged anions $\mathrm{H}_{2} \mathrm{AsO}_{4}{ }^{-}$and $\mathrm{HAsO}_{4}{ }^{2-}$ compared with $\mathrm{Al}(\mathrm{OH})_{3}-\mathrm{F}_{\text {coag }}$, as indicated in Equations (7) and (8).

The adsorption of arsenic onto aluminum (hydro) oxides is highly dependent on the interfacial hydroxyl groups $(-\mathrm{OH})$, and the formation of surface complexes plays an important role. Figure 8 illustrates the FTIR spectra of $\mathrm{Al}(\mathrm{OH})_{3}-\mathrm{F}_{\mathrm{ads}}$, $\mathrm{Al}(\mathrm{OH})_{3}-\mathrm{F}_{\text {coag }}$, and $\mathrm{Al}(\mathrm{OH})_{3}$ before and after the adsorption of $\mathrm{As}(\mathrm{III})$ and $\mathrm{As}(\mathrm{V})$. These three adsorbents show a broad band centered at $960 \mathrm{~cm}^{-1}$, which corresponds to the bending vibration of the $-\mathrm{OH}$ groups on their surfaces (Sun and Doner, 1996). Moreover, the intensity of the hydroxyl band on $\mathrm{Al}(\mathrm{OH})_{3}-\mathrm{F}_{\text {coag }}$ is stronger than on $\mathrm{Al}(\mathrm{OH})_{3}-\mathrm{F}_{\text {ads }}$ and $\mathrm{Al}(\mathrm{OH})_{3}$, indicating more $-\mathrm{OH}$ sites on the surface. As mentioned above, coprecipitation and adsorption are involved in the removal of fluoride by coagulation and Al-F-OH participates formed thereafter (Gong et al., 2012). These peaks reduce 

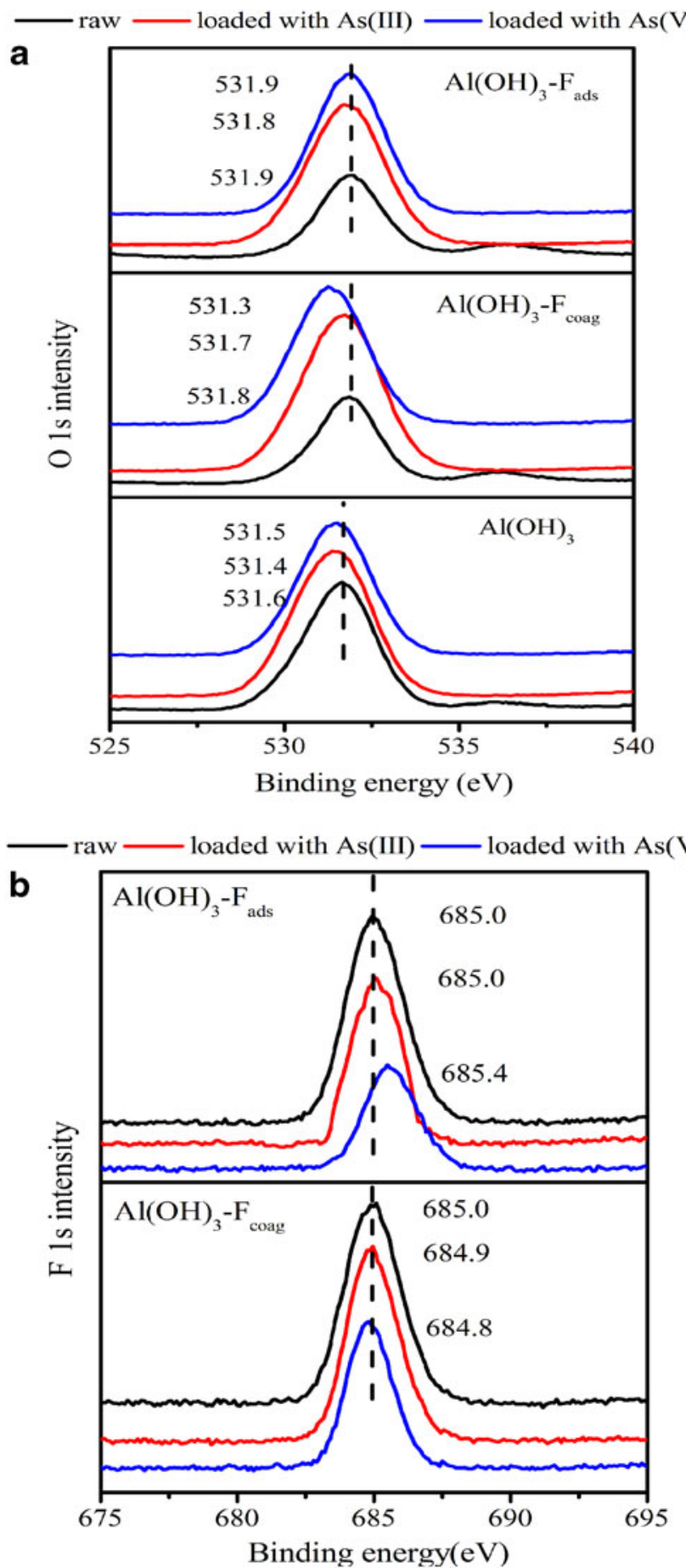

FIG. 7. X-ray photoelectron spectroscopy spectra of (a) $\mathrm{O} 1 \mathrm{~s}$ and (b) F $1 \mathrm{~s}$ on the surfaces of the three adsorbents.

remarkably after the adsorption of As(III) and As(V), owing to the participation and the consumption of $-\mathrm{OH}$ groups by arsenic species. In addition, new peaks at 997 and $870 \mathrm{~cm}^{-1}$ appear that are assigned to the $\mathrm{O}-\mathrm{As}(\mathrm{III})$ and $\mathrm{O}-\mathrm{As}(\mathrm{V})$ stretching vibrations (Sun and Doner, 1996). Only a slight difference is observed in the intensity of O-As(III) on the three adsorbents. By contrast, the intensity of $\mathrm{O}-\mathrm{As}(\mathrm{V})$ on $\mathrm{Al}(\mathrm{OH})_{3}-\mathrm{F}_{\text {ads }}$ is much weaker than that on $\mathrm{Al}(\mathrm{OH})_{3}-\mathrm{F}_{\text {coag }}$ and $\mathrm{Al}(\mathrm{OH})_{3}$. This indicates that the surface complexation is less

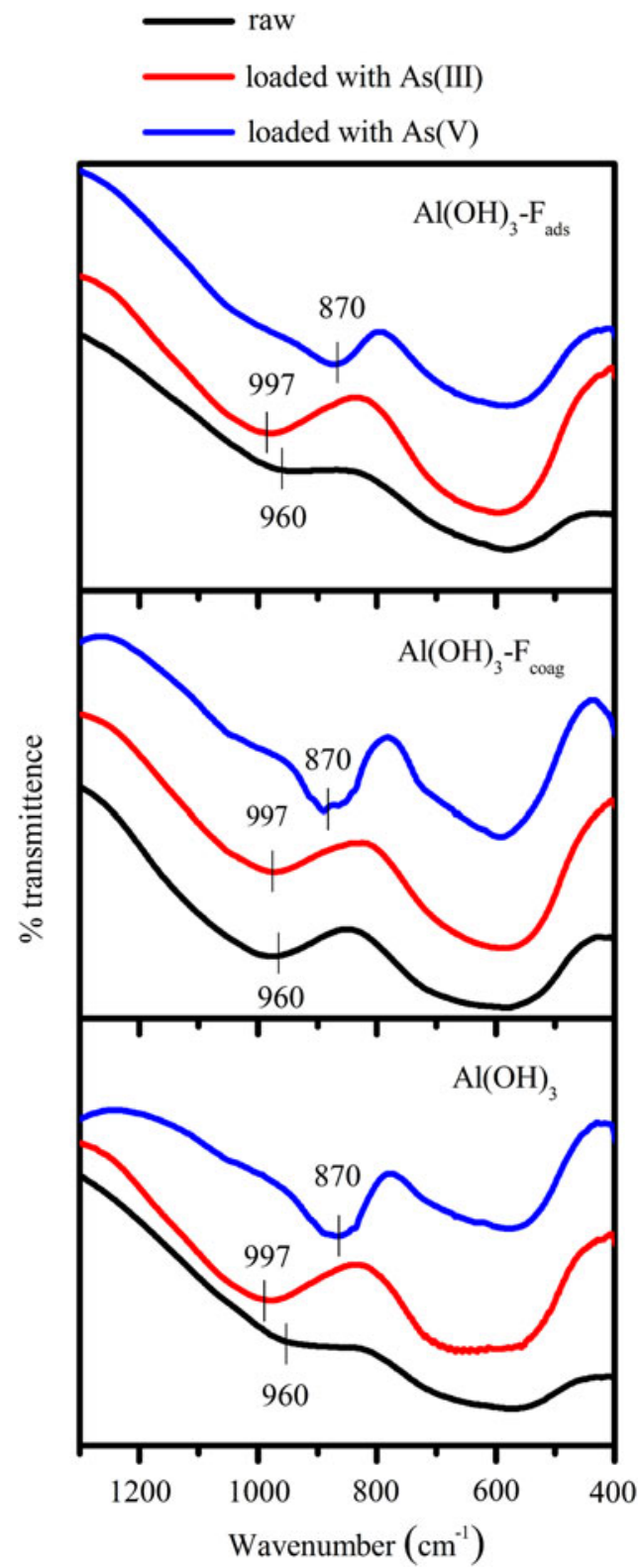

FIG. 8. Fourier transform infrared spectroscopy (FTIR) spectra of adsorbents before and after adsorption of As(III) and $\mathrm{As}(\mathrm{V})$

dominant in $\mathrm{Al}(\mathrm{OH})_{3}-\mathrm{F}_{\text {ads }}$ than $\mathrm{Al}(\mathrm{OH})_{3}-\mathrm{F}_{\text {coag }}$ and $\mathrm{Al}(\mathrm{OH})_{3}$, in agreement with the XPS results.

\section{Conclusions}

The Al-based solid wastes generated from fluoride removal by adsorption and coagulation, $\mathrm{Al}(\mathrm{OH})_{3}-\mathrm{F}_{\text {coag }}$ and $\mathrm{Al}(\mathrm{OH})_{3}-\mathrm{F}_{\text {ads }}$, were characterized and applied for adsorptive removal of $\mathrm{As}(\mathrm{III})$ and $\mathrm{As}(\mathrm{V})$ from the aqueous solution. Kinetic study results indicate that $\mathrm{As}(\mathrm{III})$ and $\mathrm{As}(\mathrm{V})$ adsorption on these Al-based solid wastes followed the pseudosecond-order model. The calculated adsorption capacity of $\mathrm{Al}(\mathrm{OH})_{3}-\mathrm{F}_{\text {ads }}$ and $\mathrm{Al}(\mathrm{OH})_{3}-\mathrm{F}_{\text {coag }}$ for $\mathrm{As}(\mathrm{III})$ was 48.0 and $31.0 \mathrm{mg} / \mathrm{g}$, while for As(V) it was 84.0 and $56.3 \mathrm{mg} / \mathrm{g}$, respectively. These adsorption capacities were $25-50 \%$ lower 
than those of pristine $\mathrm{Al}(\mathrm{OH})_{3}$. Anion exchange of fluoride by $\mathrm{H}_{2} \mathrm{AsO}_{4}{ }^{-}$and $\mathrm{HAsO}_{4}{ }^{2-}$ dominated in $\mathrm{As}(\mathrm{V})$ removal by $\mathrm{Al}(\mathrm{OH})_{3}-\mathrm{F}_{\mathrm{ads}}$, while formation of an As-O complex played a more important role in $\mathrm{As}(\mathrm{V})$ removal by $\mathrm{Al}(\mathrm{OH})_{3}-\mathrm{F}_{\text {coag }}$. The maximum concentration of released fluoride after the adsorption of $\mathrm{As}(\mathrm{III})$ and $\mathrm{As}(\mathrm{V})$ by $\mathrm{Al}(\mathrm{OH})_{3}-\mathrm{F}_{\text {ads }}$ and $\mathrm{Al}(\mathrm{OH})_{3^{-}}$ $\mathrm{F}_{\text {coag }}$ was below the Chinese Class-II industrial discharge standard for fluoride $(<20 \mathrm{mg} / \mathrm{L})$. The solid wastes generated in fluoride removal processes could be potentially utilized as adsorbents for $\mathrm{As}(\mathrm{III}) / \mathrm{As}(\mathrm{V})$ removal from industrial wastewater. It it noted that the arsenic content in the obtained solid wastes exceeds the Identification Standards for Hazardous Wastes of China and should be carefully and safely handled and disposed. The strategy for the stabilization and safe disposal of these solid wastes is to be studied in the future.

\section{Acknowledgments}

This work was supported by the National Natural Science Foundation of China (Grant no. 21177143 and 21177144) and the key project of the National "863" High-tech R\&D Program of China (2012AA062604). Appreciation is also extended to the Outstanding Youngster Fund (51422813) and Joint Research Fund for Overseas Chinese Scholars and Scholars in Hong Kong and Macao (51328803).

\section{Author Disclosure Statement}

No competing financial interests exist.

\section{References}

Baciocchi, R., Chiavola, A., and Gavasci, R. (2005). Ion exchange equilibria of arsenic in the presence of high sulphate and nitrate concentrations. Water Supply 5, 67.

Borho, M., and Wilderer, P. (1996). Optimized removal of arsenate (III) by adaptation of oxidation and precipitation processes to the filtration step. Water Sci. Technol. 34, 25.

Cheng, R.C., Liang, S., Wang, H.-C., and Beuhler, M.D. (1994). Enhanced coagulation for arsenic removal. J. Am. Water Works Assoc. 86, 79.

Gong, W.X., Qu, J.H., Liu, R.P., and Lan, H.C. (2012). Effect of aluminum fluoride complexation on fluoride removal by coagulation. Colloid. Surface. A 395, 88.

Guo, H., Stüben, D., and Berner, Z. (2007). Adsorption of arsenic (III) and arsenic (V) from groundwater using natural siderite as the adsorbent. J. Colloid. Interface Sci. 315, 47.

Hering, J.G., Chen, P.-Y., Wilkie, J.A., and Elimelech, M. (1997). Arsenic removal from drinking water during coagulation. J. Environ. Eng. 123, 800.

Ho, Y.S., and McKay, G. (1999). Pseudo-second order model for sorption processes. Process Biochem. 34, 451.

Kang, M., Kawasaki, M., Tamada, S., Kamei, T., and Magara, Y. (2000). Effect of $\mathrm{pH}$ on the removal of arsenic and antimony using reverse osmosis membranes. Desalination 131, 293.

Katsoyiannis, I., Zouboulis, A., Althoff, H., and Bartel, H. (2002). As (III) removal from groundwaters using fixed-bed upflow bioreactors. Chemosphere 47, 325.

Kim, J., and Benjamin, M.M. (2004). Modeling a novel ion exchange process for arsenic and nitrate removal. Water Res. $38,2053$.
Leupin, O.X., and Hug, S.J. (2005). Oxidation and removal of arsenic (III) from aerated groundwater by filtration through sand and zero-valent iron. Water Res. 39, 1729.

Lin, T.F., and Wu, J.K. (2001). Adsorption of arsenite and arsenate within activated alumina grains: Equilibrium and kinetics. Water Res. 35, 2049.

Liu, R., Gong, W., Lan, H., Yang, T., Liu, H., and Qu, J. (2012). Simultaneous removal of arsenate and fluoride by iron and aluminum binary oxide: Competitive adsorption effects. Sep. Purif. Technol. 92, 100.

Luo, X., Wang, C., Luo, S., Dong, R., Tu, X., and Zeng, G. (2012). Adsorption of As (III) and As (V) from water using magnetite $\mathrm{Fe}_{3} \mathrm{O}_{4}$-reducedgraphite oxide- $\mathrm{MnO}_{2}$ nanocomposites. Chem. Eng. J. 187, 45.

Maiti, A., Basu, J.K., and De, S. (2012). Experimental and kinetic modeling of As (V) and As (III) adsorption on treated laterite using synthetic and contaminated groundwater: Effects of phosphate, silicate and carbonate ions. Chem. Eng. J. 191,1

Mandal, S., Majumder, N., Chowdhury, C., Ganguly, D., Dey, M., and Jana, T. (2012). Adsorption kinetic control of As (III and V) mobilization and sequestration by Mangrove sediment. Environ. Earth Sci. 65, 2027.

Mckay, G., Blair, H., and Gardner, J. (1982). Adsorption of dyes on chitin. I. Equilibrium studies. J. Appl. Polym. Sci. 27, 3043.

Mohan, D., and Pittman, C.U., Jr. (2007). Arsenic removal from water/wastewater using adsorbents-a critical review. $J$. Hazard. Mater. 142, 1.

Ning, R.Y. (2002). Arsenic removal by reverse osmosis. Desalination 143, 237.

Ona-Nguema, G., Morin, G., Juillot, F., Calas, G., and Brown, G.E. (2005). EXAFS analysis of arsenite adsorption onto twoline ferrihydrite, hematite, goethite, and lepidocrocite. Environ. Sci. Technol. 39, 9147.

Shiowatana, J., McLaren, R.G., Chanmekha, N., and Samphao, A. (2001). Fractionation of arsenic in soil by a continuousflow sequential extraction method. J. Environ. Qual. 30, 1940.

Soner Altundoğan, H., Altundoğan, S., Tümen, F., and Bildik, M. (2000). Arsenic removal from aqueous solutions by adsorption on red mud. Waste Manage. 20, 761.

Sun, X., and Doner, H.E. (1996). An investigation of arsenate and arsenite bonding structures on goethite by FTIR. Soil Sci. $161,865$.

Weng, Y.-H., Chaung-Hsieh, L.H., Lee, H.-H., Li, K.-C., and Huang, C. (2005). Removal of arsenic and humic substances (HSs) by electro-ultrafiltration (EUF). J. Hazard. Mater. 122,171 .

Wickramasinghe, S., Han, B., Zimbron, J., Shen, Z., and Karim, M. (2004). Arsenic removal by coagulation and filtration: Comparison of groundwaters from the United States and Bangladesh. Desalination 169, 231.

Wu, K., Liu, R., Liu, H., Chang, F., Lan, H., and Qu, J. (2011). Arsenic species transformation and transportation in arsenic removal by Fe-Mn binary oxide-coated diatomite: Pilot-scale field study. J. Environ. Eng. 137, 1122.

$\mathrm{Xu}, \mathrm{Z}$., and Meng, X. (2009). Size effects of nanocrystalline $\mathrm{TiO}_{2}$ on As (V) and As (III) adsorption and As (III) photooxidation. J. Hazard. Mater. 168, 747.

Yuh-Shan, H. (2004). Citation review of Lagergren kinetic rate equation on adsorption reactions. Scientometrics 59, 171. 